\title{
Calcium Chloride Extractable Cadmium as an estimate of Cadmium Uptake by Subterranean Clover
}

\author{
M. G. Whitten and G. S. P. Ritchie
}

\begin{abstract}
Cadmium (Cd) may accumulate in soils which have been regularly fertilized with phosphate fertilizers which contain $\mathrm{Cd}$ originating in rock phosphate. Soil was taken from three sites in the wheatbelt of Western Australia which were estimated to have received different amounts of phosphate fertilizer over the past decade. The $\mathrm{pH}$ was adjusted with dilute $\mathrm{HCl}$ or $\mathrm{CaCO}_{3}$. No $\mathrm{Cd}$ was added experimentally. The concentration of $\mathrm{Cd}$ in the whole tops of Trifolium subterraneum cv Mt Barker grown in a glasshouse pot experiment increased from $0 \cdot 2-0 \cdot 8 \mu \mathrm{g}$ $\mathrm{g}^{-1}$ dry wt at $\mathrm{pH} 6 \cdot 6-6 \cdot 9\left(1: 50.01 \mathrm{M} \mathrm{CaCl}_{2}\right)$ to $2-4 \mu \mathrm{g} \mathrm{g}^{-1}$ at $\mathrm{pH} 4 \cdot 1-4 \cdot 2$. The highest concentration of $\mathrm{Cd}$ in the plant tops at any particular $\mathrm{pH}$ occurred on the soil which had the highest concentration of $\mathrm{P}$ in the $\mathrm{CaCl}_{2}$ extract. There was a linear relationship between the concentration of $\mathrm{Cd}$ in the whole tops of sub-clover and the concentration of $\mathrm{Cd}$ in the $\mathrm{CaCl}_{2}$ extracts which was independent of site. The concentration of $\mathrm{Cd}$ in the $\mathrm{CaCl}_{2}$ extracts was a function of $\mathrm{pH}$ and concentration of $\mathrm{P}$ in the $\mathrm{CaCl}_{2}$ extract.
\end{abstract}

\section{Introduction}

Cadmium (Cd) can enter the agricultural food chain via the disposal of sewage sludge on agricultural land, accumulation in soil from industrial pollution (Cartwright et al. 1976; Merry and Tiller 1978) or application of phosphate fertilizers (Williams and David 1973). Superphosphate in Australia may contain up to $50 \mu \mathrm{g} \mathrm{g}^{-1}$ cadmium (Williams and David 1973), approximately $50 \%$ of which is water-soluble (Mann 1989). The Cd content of pasture species has been shown to increase with the total amount of superphosphate applied (Williams and David 1973) or when soil pH was decreased (Williams 1977; Tiller 1988). The concentration of Cd in plants grown on soils in which the $\mathrm{pH}$ ranged from strongly acid to slightly acid or alkaline was poorly correlated with soil Cd extracted by acid or EDTA (Symeonides and McRae 1977) or DTPA (Kuo 1990).

The objectives of this work were to examine the effect of $\mathrm{pH}$ on the concentration of $\mathrm{Cd}$ in subterranean clover grown on three acid soils from the Western Australian wheatbelt and to determine whether $\mathrm{Cd}$ in $\mathrm{CaCl}_{2}$ soil extracts was a good measure of plant-available $C d$.

\section{Materials and Methods}

The concentration of Cd was measured in Trifolium subterraneum L. CV Mt Barker grown in soil from three sites which had been acidified or limed to give a $\mathrm{pH}$ range of approximately 4-7 (1: $\left.50.01 \mathrm{M} \mathrm{CaCl}_{2}\right)$. 


\section{Experimental Procedure}

Sites on three farms in the Western Australian wheatbelt (Table 1) were sampled to a depth of approximately $10 \mathrm{~cm}$ after clearing the surface of plant debris. The soils were air-dried and sieved $(\leq 2 \mathrm{~mm})$ immediately after collection. The sites differed in recent mangement histories. Site 1 was in the pasture phase of a long rotation, site 2 had been continuously cropped for the past 10 years and site 3 was in the crop phase of a short crop:pasture rotation.

Table 1. Summary of soils

The vicinities of the soil sites were: site 1, Meckering; site 2, Goomalling; site 3, Merredin

\begin{tabular}{|c|c|c|c|c|c|c|c|c|c|c|}
\hline \multirow[t]{2}{*}{ Site } & \multirow[t]{2}{*}{$\begin{array}{l}\text { Classifica- } \\
\text { tion }^{A}\end{array}$} & \multirow[t]{2}{*}{$\mathrm{pH}^{\mathrm{B}}$} & \multirow{2}{*}{$\begin{array}{c}\text { Bic- }^{-} \\
\mathrm{PC}^{\mathrm{C}} \\
\left(\mu \mathrm{g} \mathrm{g}^{-1}\right)\end{array}$} & \multirow[t]{2}{*}{$\mathrm{PRI}^{\mathrm{D}}$} & \multicolumn{2}{|c|}{$\begin{array}{c}\text { Ox. extract. } \\
\left(\mu \mathrm{g} \mathrm{g}^{-1}\right)\end{array}$} & \multirow{2}{*}{$\begin{array}{c}\text { Org. } \\
\mathrm{C}^{\mathrm{F}} \\
(\%)\end{array}$} & \multicolumn{3}{|c|}{$\begin{array}{c}\text { Particle size } \\
\text { (\%) }\end{array}$} \\
\hline & & & & & $\mathrm{Al}$ & $\mathrm{Fe}$ & & Sand & Silt & Clay \\
\hline 1 & Dy 5.51 & $4 \cdot 4$ & $15 \cdot 8$ & $1 \cdot 43$ & 178 & 261 & $1 \cdot 0$ & 90 & 4 & 6 \\
\hline 2 & Dy $5 \cdot 51$ & $4 \cdot 4$ & $23 \cdot 5$ & $0 \cdot 75$ & 175 & 155 & $1 \cdot 0$ & 88 & 4 & 7 \\
\hline 3 & Gn $2 \cdot 21$ & $4 \cdot 8$ & $20 \cdot 6$ & $4 \cdot 43$ & 285 & 687 & $1 \cdot 3$ & 80 & 3 & 17 \\
\hline
\end{tabular}

A Northcote (1984).

B $1: 50.01 \mathrm{M} \mathrm{CaCl}_{2}$.

C Bicarbonate extractable P (Colwell 1963).

${ }^{D}$ Phosphate retention index: $\mathrm{P}$ adsorbed by $1 \mathrm{~g}$ soil in $10 \mathrm{~mL} 0.01 \mathrm{M} \mathrm{KCl}$ initially containing $10 \mu \mathrm{g} \mathrm{mL}^{-1} \mathrm{P}$ as $\mathrm{KH}_{2} \mathrm{PO}_{4}$ divided by the final concentration of $\mathrm{P}$.

E Oxalate extractable P; $3 \mathrm{~g}$ soil $100 \mathrm{~mL}^{-1}$ acid ammonium oxalate (Searle and Daly 1977).

F Yeomans and Bremner (1988).

Although precise fertilizer histories are not known, site 2 is estimated to have received more phosphate fertilizer than the other two sites for the past 10 years at least. There was no known environmental or industrial source of $\mathrm{Cd}$ near the collection sites or the buildings where the experiment took place.

The glasshouse experiment consisted of subterranean clover grown in pots in root-cooling tanks in a factorial array of 3 soils, $8 \mathrm{pH}$ values, 2 sources of nitrogen $\left(\mathrm{N}_{2}\right.$ fixation and $\mathrm{NH}_{4} \mathrm{NO}_{3}$ ) with three replicates and has been described in detail elsewhere (Whitten and Ritchie 1991). The $\mathrm{pH}$ treatments were dilute $\mathrm{HCl}$ (range: $0.06-0.8 \mathrm{cmol} \mathrm{H}^{+} \mathrm{kg}^{-1}$ ), nil (deionized water) or precipitated $\mathrm{CaCO}_{3}(1 \cdot 25$ and $2.5 \mathrm{~g}$ per $3 \mathrm{~kg}$ pot) followed by incubation at field capacity for 8 days at $40^{\circ} \mathrm{C}$. Nutrient solutions supplying (mg kg-1 soil) $\mathrm{Na}_{2} \mathrm{MoO}_{4} \cdot 2 \mathrm{H}_{2} \mathrm{O}$ $(0.67), \mathrm{H}_{3} \mathrm{BO}_{3}(0 \cdot 83), \mathrm{CuSO}_{4} .5 \mathrm{H}_{2} \mathrm{O}(5), \mathrm{ZnSO}_{4} .7 \mathrm{H}_{2} \mathrm{O}(10), \mathrm{MnSO}_{4} . \mathrm{H}_{2} \mathrm{O}(15), \mathrm{CoSO}_{4} .7 \mathrm{H}_{2} \mathrm{O}(0 \cdot 4)$, $\mathrm{K}_{2} \mathrm{SO}_{4}$ (145), and $\mathrm{KH}_{2} \mathrm{PO}_{4}[110$ (soils 1 and 2) and 176 (soil 3)] were applied as solutions to the surface of the soil which was then dried and mixed. The $\mathrm{N}$-fertilized treatments received $24 \mathrm{mg} \mathrm{N}$ kg soil as $\mathrm{NH}_{4} \mathrm{NO}_{3}$ before sowing and at 10 day intervals thereafter. Plants were harvested at 5 weeks and were washed in deionized water to remove any adhering soil particles. No $\mathrm{Cd}$ was added experimentally and all reagents for $\mathrm{pH}$ adjustments and nutrients were analytical grade.

\section{Cadmium Analysis of Plants and Soils}

All labware for $\mathrm{Cd}$ analysis was cleaned in $1 \mathrm{M} \mathrm{HCl}$ and $0.1 \mathrm{M} \mathrm{Na} 2$ EDTA. The undiluted nitric/perchloric acid digest of the whole tops of the subterranean clover was analysed for $\mathrm{Cd}$ by flame atomic absorption spectrophotometry (FAAS) on a Perkin-Elmer 5000 atomic absorption spectrophotometer using background correction to eliminate interference from non-atomic absorption. The range of measured $\mathrm{Cd}$ in reference plant material (kale; Bowen 1975) was $0.64 \pm 0.12 \mu \mathrm{g} \mathrm{g}^{-1}$. Bowen (1975) reported the $C d$ concentration of this reference material to be $1 \cdot 00 \pm 0 \cdot 19 \mu \mathrm{g} \mathrm{g}^{-1}$ when analysed by AAS, but suggested that this was an overestimation by $32 \%$ because of non-atomic absorption. Standards from a stock solution of $\mathrm{Cd}$ metal dissolved in $\mathrm{HCl}$ were made up in perchloric acid.

Subsamples of soil which had not received nutrients were shaken end-over-end for $16 \mathrm{~h}$ at $20^{\circ} \mathrm{C}$ in $1: 50.01 \mathrm{M} \mathrm{CaCl}_{2}$, made up from a stock solution which had been purified 
with dithizone extracted into chloroform to remove any trace amounts of $\mathrm{Cd}$. The extracts were filtered through $0.4 \mu \mathrm{m}$ polycarbonate membranes (Nuclepore Corporation, U.S.A.). Cadmium in the filtrate was complexed with ammonium pyrrolidine dithiocarbamate (APDC) and extracted into 4-methylpentan-2-one (syn. methyl isobutyl ketone, MIBK) according to the method of Dudas (1974) in order to eliminate potential matrix effects during analysis. The MIBK extract was then analysed for Cd by flameless AA using pyrolytically coated graphite tubes in a Perkin-Elmer HGA 500 graphite furnace coupled to a PE 5000 with background correction. Standards were made up in double-deionized water immediately before complexing with APDC and extracting into MIBK.

The $\mathrm{pH}$ and concentration of $\mathrm{P}$ in the $\mathrm{CaCl}_{2}$ extracts were measured with an Orion EA $940 \mathrm{pH}$ meter and by the method of John (1970), respectively.

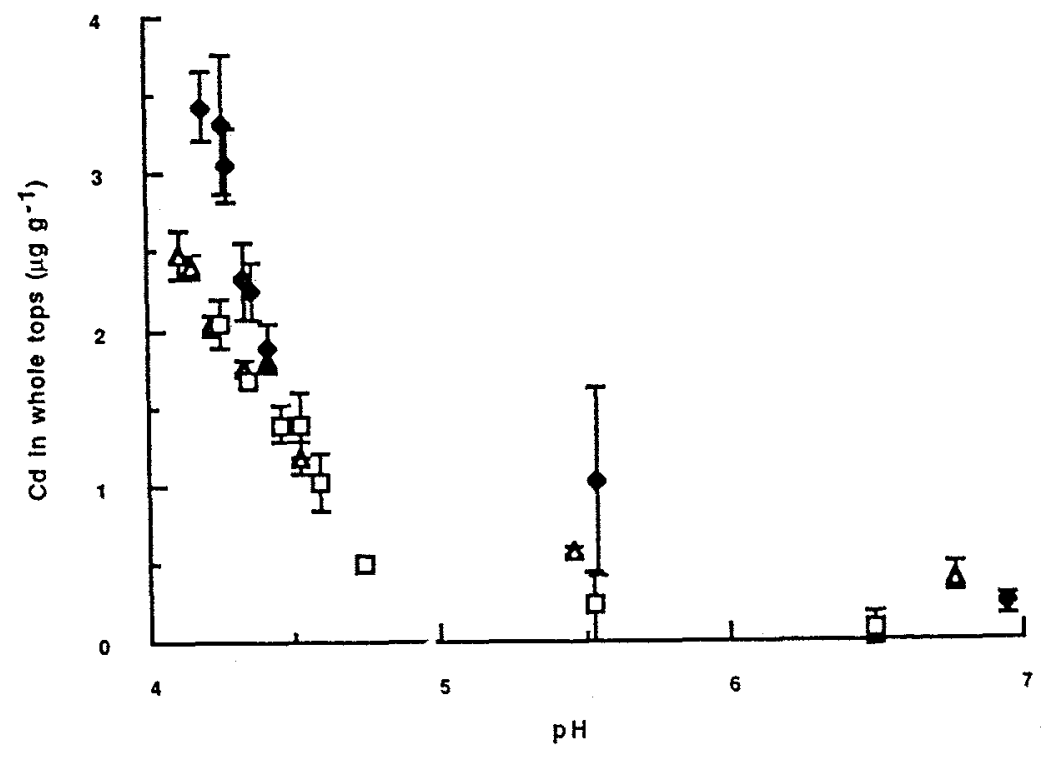

Fig. 1. Concentration of $\mathrm{Cd}\left(\mu \mathrm{g} \mathrm{g}^{-1}\right)$ in the whole tops of subterranean clover plotted against $\mathrm{pH}$ in $1: 5$ extract in $0.01 \mathrm{M} \mathrm{CaCl}_{2}$. Symbols $(\triangle)$ site $1,(\diamond)$ site 2 and (ㅁ) site 3 . Error bars indicate standard errors.

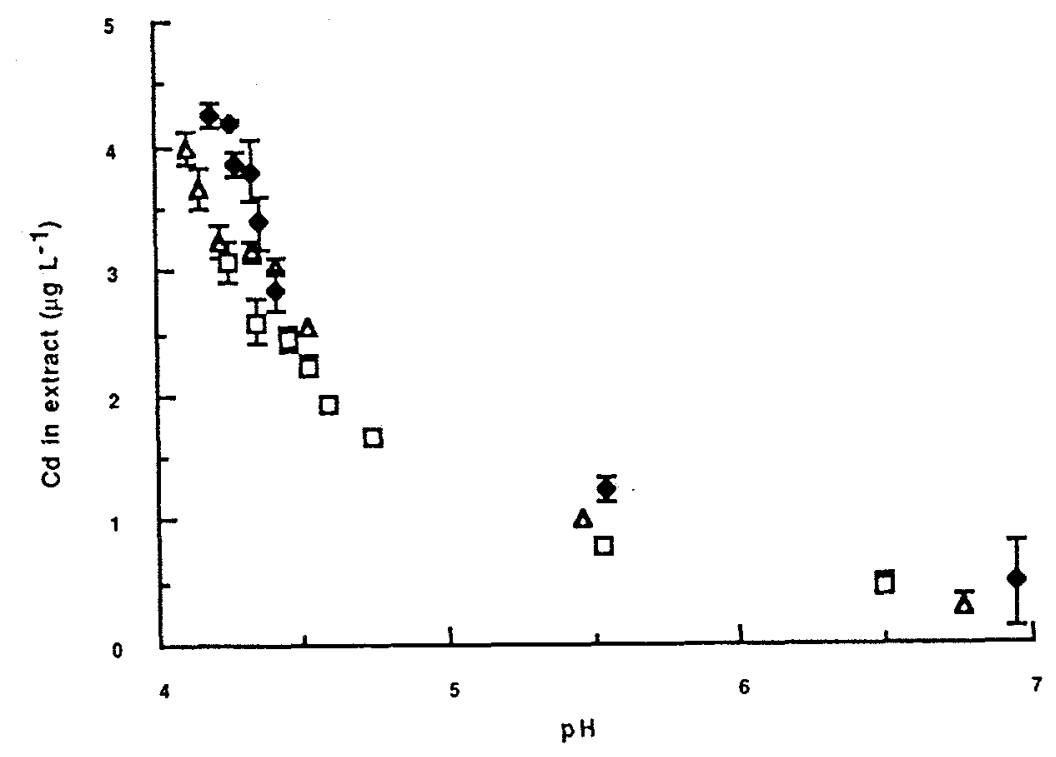

Fig. 2. Concentration of $\mathrm{Cd}\left(\mu \mathrm{g} \mathrm{L}^{-1}\right)$ plotted against $\mathrm{pH}$ in $1: 5$ extract in $0.01 \mathrm{M} \mathrm{CaCl}_{2}$. Symbols $(\triangle)$ site $1,(\bullet)$ site 2 and $(\square)$ site 3 . Error bars indicate standard errors. 


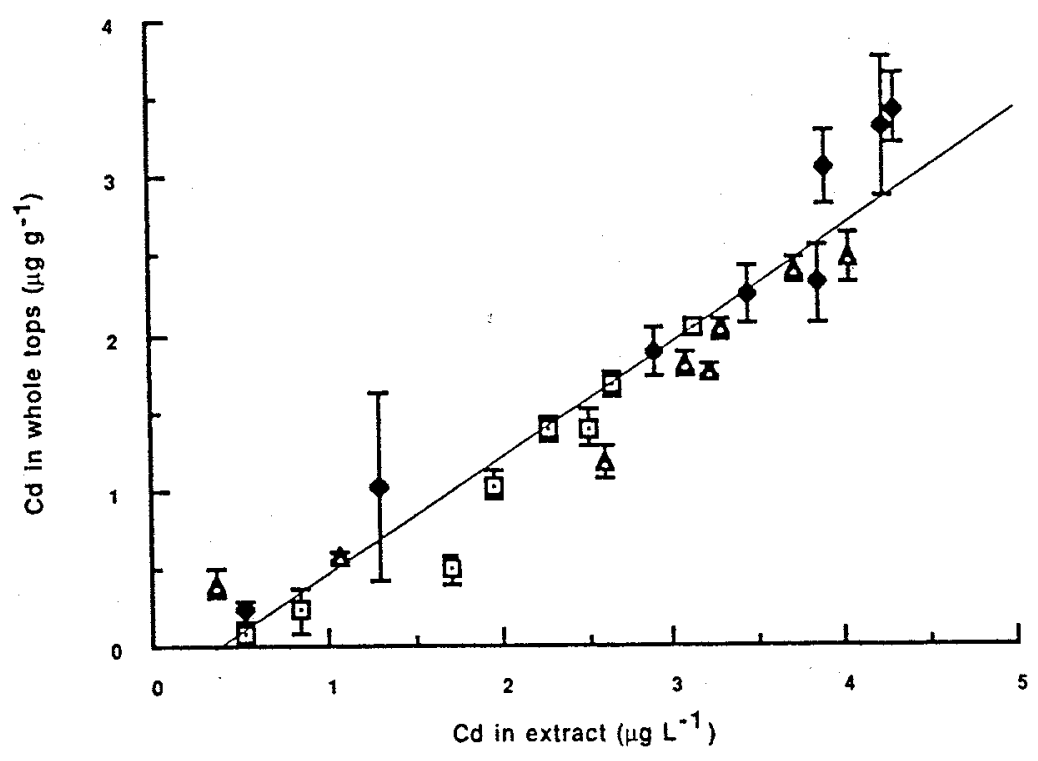

Fig. 3. Concentration of $\mathrm{Cd}\left(\mu \mathrm{g} \mathrm{g}^{-1}\right)$ in the whole tops of subterranean clover plotted against $\mathrm{Cd}\left(\mu \mathrm{g} \mathrm{L}^{-1}\right)$ in $1: 5$ extract in $0.01 \mathrm{M} \mathrm{CaCl}_{2}$. Symbols $(\Delta)$ site $1,(\diamond)$ site 2 and (口) site 3. Error bars indicate standard errors.

\section{Results}

The concentration of $\mathrm{Cd}$ in the whole tops of the subterranean clover increased from $0.2-0.8 \mu \mathrm{g} \mathrm{g}-1$ dry wt at $\mathrm{pH} 6 \cdot 6-6 \cdot 9$ to $2-4 \mu \mathrm{g} \mathrm{g}^{-1}$ at $\mathrm{pH}$ $4 \cdot 1-4 \cdot 2$ (Fig. 1). In the soil extracts, there was a corresponding increase in the concentration of $\mathrm{Cd}$ from $0 \cdot 3-0 \cdot 5 \mu \mathrm{g} \mathrm{\textrm {L } ^ { - 1 }}$ to $3 \cdot 0-4 \cdot 3 \mu \mathrm{g} \mathrm{L}^{-1}$ (Fig. 2). The relationship between the concentration of $\mathrm{Cd}$ in the whole tops of $\mathrm{N}$-fixing subterranean clover and $\mathrm{Cd}$ in the $\mathrm{CaCl}_{2}$ extracts was

$$
\mathrm{Cd}\left(\mu \mathrm{g} \mathrm{g}^{-1}\right)=-0 \cdot 301+0 \cdot 775 \mathrm{Cd}\left(\mu \mathrm{g} \mathrm{L}^{-1}\right) \text {, }
$$

$\left(P<0.01\right.$, adj. $\left.r^{2}=0.91\right)$ and was independent of site (Fig. 3).

The highest concentration of $\mathrm{Cd}$ in the plant tops at any particular $\mathrm{pH}$ occurred on soil 2 which had the highest concentration of phosphate in bicarbonate and $\mathrm{CaCl}_{2}$ extracts. Although there was a significant $(P<0.01)$ linear relationship between the concentrations of $\mathrm{Cd}$ and $\mathrm{P}$ in the $\mathrm{CaCl}_{2}$ extracts, the concentration of $\mathrm{P}$ accounted for only $24.5 \%$ of the variation in the concentration of $\mathrm{Cd}$. The concentration of $\mathrm{Cd}$ in the $\mathrm{CaCl}_{2}$ extracts was best predicted by multiple linear regression against both the $\mathrm{pH}$ and the concentration of $\mathrm{P}$ in the $\mathrm{CaCl}_{2}$ extract. The regression equation was

$$
\mathrm{Cd}\left(\mu \mathrm{g} \mathrm{L}^{-1}\right)=7 \cdot 7348-1 \cdot 146 \mathrm{pH}+3 \cdot 541 \mathrm{P}\left(\mathrm{mg} \mathrm{L}^{-1}\right) \text {. }
$$

Both $\mathrm{pH}$ and $\mathrm{P}$ were significant $(P=0.0001)$ and the adjusted $r^{2}$ was 0.903 .

Plants fertilized with $\mathrm{NH}_{4} \mathrm{NO}_{3}$ contained slightly more $\mathrm{Cd}$ than those which relied on symbiotically fixed $\mathrm{N}$. The relationship was

$$
\mathrm{Cd}\left(\mu \mathrm{g} \mathrm{g}^{-1}\right) \mathrm{N} \text {-fertilized }=0 \cdot 27+1 \cdot 132 \mathrm{Cd}\left(\mu \mathrm{g} \mathrm{g}^{-1}\right) \mathrm{N} \text {-fixing }
$$

$\left(P=0.0001\right.$, adj. $\left.r^{2}=0 \cdot 92\right)$. 


\section{Discussion}

Calcium chloride extractable $\mathrm{Cd}$ was a good indicator of the $\mathrm{Cd}$ content of subterranean clover. The concentration of $\mathrm{Cd}$ in the plant material and the $\mathrm{CaCl}_{2}$ extracts increased in a similar manner as the $\mathrm{pH}$ of the soil decreased.

\section{Cadmium in Sub-clover}

The concentration of $\mathrm{Cd}$ in subterranean clover nearly doubled in each of the W.A. soils as the pH decreased from about 4.5 to 4 and was approximately halved as the $\mathrm{pH}$ increased from about $4 \cdot 5$ to about 5.5. The highest concentration of $\mathrm{Cd}$ in the whole tops of subterranean clover occurred in soil from site 2 which is estimated to have received the most phosphate fertilizer during the last 10 years. In Western Australia, therefore, acidification of soils used for pasture production could increase the uptake of $\mathrm{Cd}$ by plants and hence grazing stock. In addition, the continued use of phosphate fertilizers manufactured from rock phosphates containing $\mathrm{Cd}$ may increase the amount of $\mathrm{Cd}$ available to plants and animals.

Variation in concentration of $\mathrm{Cd}$ in plants could also be due to differences between soil type. Tiller (1988) reported twofold differences in the concentration of $\mathrm{Cd}$ in sub-clover growing in a red podzolic and a solodized solonetz over a pH range spanning 5.5-8.5 (1:5 water). These differences decreased with the addition of $\mathrm{Cd}$.

The slightly higher concentration of $\mathrm{Cd}$ in the plant material from the $\mathrm{N}$-fertilized treatment compared with the $\mathrm{N}$-fixing treatment may be due to displacement of exchangeable $\mathrm{Cd}$ by $\mathrm{NH}_{4}^{+}$or a slightly lower soil $\mathrm{pH}$ in the $\mathrm{N}$-fertilized treatment. However, the final $\mathrm{pH}$ of the $\mathrm{N}$-fertilized treatments was estimates to be only marginally lower than in the $\mathrm{N}$-fixing treatments. This estimate was based on the differences in final soil $\mathrm{pH}$ under clover with different sources of $\mathrm{N}$ supplied at $350 \mathrm{mg}$ at $\mathrm{N}$ per $3 \mathrm{~kg}$ pot under conditions similar to our experiment and with a soil of similar pH buffering capacity (Jarvis and Robson, 1983). It was calculated that production of $1 \mathrm{~g}$ shoot dry matter in our experiment would generate an excess of $\mathrm{H}^{+}$in the $\mathrm{N}$-fertilized treatment compared with the $\mathrm{N}$-fixing treatment of approximately $2 \times 10^{-6} \mathrm{~mol} \mathrm{~L}^{-1}$ in the $\mathrm{CaCl}_{2}$ extract. This would be equivalent to a difference of approximately 0.04 $\mathrm{pH}$ units if the final $\mathrm{pH}$ was $4 \cdot 5$ in the $\mathrm{N}$-fixing treatment.

\section{Cadmium and Phosphorus in the Soil Extracts}

The concentration of $\mathrm{Cd}$ in the extracts was a function of $\mathrm{pH}$ and concentration of $\mathrm{P}$ in the extract. The correlation between the concentrations of $\mathrm{Cd}$ and $\mathrm{P}$ in the $\mathrm{CaCl}_{2}$ extract was poor in comparison with that for $\mathrm{Cd}$ extracted with $1 \mathrm{M} \mathrm{HCl}$ and $\mathrm{P}$ extracted with $0.5 \mathrm{M} \mathrm{H}_{2} \mathrm{SO}_{4}$ (Williams and David 1973; $r^{2}$ not stated therein), or between $\mathrm{Cd}$ extracted with $0.1 \mathrm{M}$ EDTA at $\mathrm{pH} 6$ and $\mathrm{P}$ in dilute $\mathrm{H}_{2} \mathrm{SO}_{4}\left(r^{2}=0.55\right.$; Merry 1988). In this work, the concentration of $\mathrm{P}$ in the $\mathrm{CaCl}_{2}$ extracts differed markedly between soils, but within each soil the effect of $\mathrm{pH}$ was much less pronounced than its effect on $\mathrm{Cd}$.

In the $\mathrm{CaCl}_{2}$ extracts, exchangeable forms of $\mathrm{Cd}$ would go into solution, whereas specifically adsorbed $\mathrm{Cd}$ would not be readily displaced by $\mathrm{Ca}$ (Tiller et al. 1979). The relationship between the concentration of $\mathrm{Cd}$ and $\mathrm{pH}$ in the 
extracts reflects increased adsorption of $\mathrm{Cd}$ with increased $\mathrm{pH}$ (Tiller et al. 1979). The amount of adsorbed Cd would also be influenced to some extent by the amount of adsorbed $\mathrm{P}$. Over the $\mathrm{pH}$ range 4-7 (which corresponds with the $\mathrm{pH}$ range of the experiment described in this paper), adsorption of $\mathrm{Cd}$ by ferric hydrous oxides has been shown to increase as the amount of adsorbed $\mathrm{P}$ increased (Kuo and McNeal 1984). At the low pH of a $1 \mathrm{M} \mathrm{HCl}$ extract, relatively little $\mathrm{Cd}$ would remain adsorbed, regardless of the amount of adsorbed $\mathrm{P}$ or the $\mathrm{pH}$ of the soil.

\section{Correlation between $C d$ in Soil Extracts and Plant Tops}

In acid soils, the concentration of $\mathrm{Cd}$ in the $1: 5 \mathrm{CaCl}_{2}$ extracts at the ionic strength of the soil solution may be a more appropriate measure of $\mathrm{Cd}$ uptake by plants than that in acidic or buffered extracts because the $\mathrm{pH}$ of the $1: 5$ extract is similar to that in the soil. Alteration of the $\mathrm{pH}$ would affect the solubility and adsorption of Cd. Symeonides and McRae (1977) found that the concentration of $\mathrm{Cd}$ in radish tops grown on soils to which $\mathrm{Cd}$ had been added ( $\mathrm{pH} 4 \cdot 8-7 \cdot 9 ; 1: 2 \cdot 5$ water) was better correlated with the concentration of soil $\mathrm{Cd}$ extracted in unbuffered $1 \mathrm{M} \mathrm{NH}_{4} \mathrm{NO}_{3}$ than in $1 \mathrm{M} \mathrm{HCl}$ or $0.00125 \mathrm{M}$ EDTA. Kuo (1990) found that the concentration of $\mathrm{Cd}$ in whole tops of Beta vulgaris L. grown on a range of soils (pH 5-5.5; $1: 2$ water) to which different rates of sewage sludge had been added was only moderately well correlated $\left(r^{2}=0.53\right)$ with DTPA extractable $\mathrm{Cd}$, and that plant $\mathrm{Cd}$ could increase as the $\mathrm{pH}$ decreased while DTPA extractable $\mathrm{Cd}$ remained constant.

\section{Conclusions}

The $\mathrm{Cd}$ extracted in $\mathrm{CaCl}_{2}$ extracts was able to predict $\mathrm{Cd}$ uptake by subterranean clover grown in agricultural soil from the three sites in which the $\mathrm{pH}$ had been altered to span the $\mathrm{pH}$ range of $4-7$ in $1: 50.01 \mathrm{M} \mathrm{CaCl}_{2}$. If similar results can be achieved over a similar soil pH range with a wider range of soil types and plant species, this test may assist in identifying sites at which Cd content of plants could be of concern. Soil acidity may be a contributing factor in the accumulation of $\mathrm{Cd}$ by grazing animals on soils to which large amounts of superphosphate containing trace amounts of $\mathrm{Cd}$ have been applied. However, soil ingestion could also be an important source of dietary $\mathrm{Cd}$ in grazing animals.

\section{Acknowledgments}

This work was based on a project on soil acidity funded by the Australian Wool Corporation. We are grateful to Dr M. McLaughlin for comments made on an earlier draft of the paper.

\section{References}

Bowen, H. J. M. (1975). The use of reference materials in the elemental analysis of biological samples. At. Energy Rev. 13, 451-77.

Cartwright, B., Merry, R. H., and Tiller, K. G. (1976). Heavy metal contamination of soils around a lead smelter at Port Pirie, South Australia. Aust. J. Soil Res. 15, 69-81.

Colwell, J. D. (1963). The estimation of phosphorus fertilizer requirements of wheat in southern New South Wales by soil analysis. Aust. J. Exp. Agric. Anim. Husb. 3, 190-7. 
Dudas, M. J. (1974). The quantitative determination of cadmium in soils by solvent extraction and flameless atomic absorption spectroscopy. Atom. Absorpt. Newsl. 13, 109-12.

Jarvis, S. C., and Robson, A. D. (1983). The effects of nitrogen nutrition of plants on the development of acidity in Western Australian soils. II. Effects of differences in cation/anion balance between plant species grown under non-leaching conditions. Aust. J. Agric. Res. 34, 355-65.

John, M. K. (1970). Colorimetric determination of phosphorus in soil and plant materials with ascorbic acid. Soil Sci. 109, 214-20.

Kuo, S. (1990). Cadmium buffering capacity and accumulation in Swiss chard in some sludge amended soils. Soil Sci. Soc. Am. J. 54, 86-91.

Kuo, S., and McNeal, B. L. (1984). Effects of $\mathrm{pH}$ and phosphate on cadmium sorption by hydrous ferric oxide. Soil Sci. Soc. Am. J. 48, 1040-4.

Mann, S. (1989). Cadmium in fertilizers and soils. Ph.D. (prelim.) Thesis, Dept Soil Science and Plant Nutrition, University of Western Australia.

Merry, R. H. (1988). Investigations on cadmium in South Australia: Rainfall, soils, cereals, pastures and soil-plant relations. In 'Cadmium Accumulations in Australian Agriculture: National Symposium, Proceedings No. 2'. (Eds J. Simpson and W. Curnow.) pp. 62-79. (Bureau of Rural Resources: Canberra.)

Merry, R. H., and Tiller, K. G. (1978). The contamination of pasture by a lead smelter in a semi-arid enviroment. Aust. J. Exp. Agric. Anim. Husb. 18, 89-96.

Northcote, K. H. (1984). 'A Factual Key for the Recognition of Australian Soils.' (Rellim: Adelaide.)

Searle, P. L., and Daly, B. K. (1977). The determination of aluminium, iron, manganese and silicon in acid oxalate soil extracts by flame emission and atomic absorption spectrometry. Geoderma 19, 1-10.

Symeonides, C., and McRae, S. G. (1977). The assessment of plant-available cadmium in soils. J. Environ. Qual. 6, 120-3.

Tiller, K. G. (1988). Cadmium accumulation in the soil-plant system: an overview in relation to possible transfers to agricultural products. In 'Cadmium Accumulations in Australian Agriculture: National Symposium, Proceedings No. 2'. (Eds J. Simpson and W. Curnow.) pp. 20-47. (Bureau of Rural Resources: Canberra.)

Tiller, K. G., Nayyar, V. K., and Clayton, P. M. (1979). Specific and non-specific sorption of cadmium by clay soils as influenced by zinc and calcium. Aust. J. Soils Res. 17, 17-28.

Whitten, M. G., and Ritchie, G. S. P. (1991). A comparison of soil tests to predict the growth and nodulation of subterranean clover in acidified topsoils. Plant Soil (in press).

Williams, C. H. (1977). Trace metals and superphosphate: toxicity problems. J. Aust. Inst. Agric. Sci. 43, 99-109.

Williams, C. H., and David, D. J. (1973). The effect of superphosphate on the cadmium content of soils and plants. Aust. J. Soil Res. 11, 43-56.

Yeomans, J. C., and Bremner, J. M. (1988). A rapid and precise method for routine determination of organic carbon in soil. Commun. Soil Sci. Plant Anal. 19, 1467-76. 